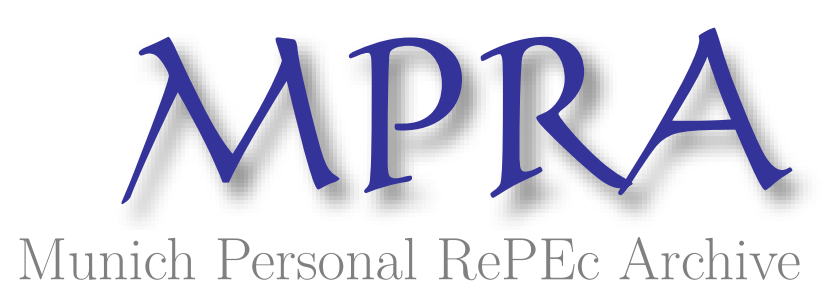

\title{
A Comparative Study on Landownership between China and England
}

\author{
Deng, Feng \\ Chongqing University
}

December 1996

Online at https://mpra.ub.uni-muenchen.de/2241/

MPRA Paper No. 2241, posted 14 Mar 2007 UTC 


\title{
A Comparative Study on Landownership between China and England
}

\author{
Feng Deng*
}

February 24, 2007

* School of Economics and Business Administration, Chongqing University, 174 Shazhengjie

Street, Shapingba District, Chongqing 400030, P. R. China. Email: fred.deng@ gmail.com

I thank Professor Martin Krieger for his comments on an early version of the paper. 


\section{A Comparative Study on Landownership between China and England}

\section{(ABSTRACT)}

By comparing the development of landownership in China and England, this paper explores what were behind their different trajectories. In particular, I examined the delineation of property rights, alienation of land, rent and tax, inheritance and accumulation of land. Feudal England was a combination of the Roman system and Anglo-Saxon tradition. From that very strict hierarchical structure England has experienced an evolution toward free land market. In contrast, since very early China has established a unique economic system that allowed free alienation of land, but it has been trying to check the development of land market and private property rights by various means, the most important of which is the strengthening and expanding of patriarchal clan system. The different development paths of China and England show the different responses of two different cultures, which are oriented toward family and individual, respectively, to the same problems related to landownership.

KEYWORDS: landownership; property rights; culture; institutions; China; England

JEL: D23, N50, P52, Q15 


\section{INTRODUCTION}

Landownership, as the foundation of property rights, has played an important role in economic history. Private land ownership, upon which the notion of private property rights are built, is often regarded as the most efficient form of ownership. Even from the perspective of equity, some also argue that establishing private property rights helps the poor (de Soto 2000). However, great diversity in the evolution of different societies suggests that private landownership is not the natural result of economic development. Even when some countries try to transplant those economic institutions that are more or less based on individualism-oriented social culture, they meet systematic resistance from deep inside the society. Furthermore, experience from widespread land reform movement in last century, regardless of their political objectives, also suggests that landownership is not just a simple matter related to economic efficiency. It is also constrained by various social factors, including our social inertia—culture.

This paper presents a comparative study on landownership between England and China. We want to answer the following questions: what are different between China and England in their development of landownership? Why are they different? What is the significance of these differences to current land policies? England is where capitalism was born and is often regarded as a typical country of western civilization, while China has a long history of a stable 'feudal' economy. ${ }^{1}$ For comparative purpose, what is also important is that China had had little communication with Western countries until the 19th century and, therefore, it developed in a relatively independent way. Moreover, both countries have long histories of recorded materials, which greatly facilitate secondary studies while simultaneously imposing great difficulty in

\footnotetext{
${ }^{1}$ In China, the word "feudal" often refers to the time period from the Warring States to Qing Dynasty (BC 453 or BC 475 - AD 1840) (see Hu, 1978). However the use of the word "feudal" is rather confusing because the Chinese society was very different from Europe throughout its long history. The intention of Chinese scholars to use the
} 
grasping the essence of their histories. Due to limitation of time and space, this paper mainly relies on second-hand materials, while trying to combine the law with the actual historical facts.

Many economic historians, institutional economists, sociologists and theorists have made great contribution to the study of property rights. There is an enormous literature that can be traced back at least to Max Weber. Recent studies include North and Thomas (1976) who argued that institutions are the crucial determinant of economic performance. North (1991) abandoned the "efficiency view of institutions" and attributed inefficient property rights to the rulers who "devised property rights in their own interests"2. Macfarlane (1979) examined the historical data on ownership in England and concluded that individualist ownership was the central feature of the English system and was peculiar to that country. Chao (1986) argued that population pressure induced the institutional changes in China. Putnam's (1994) study confirmed the relationship between institutional performance and civic tradition in Italy. Greif (1994) analyzed how cultural beliefs account for societal organizations and their path dependence. All these studies broadened our understanding of culture and institutions, but most of them deal with the issue in a general way, seldom focusing on landownership.

Through a brief review of the evolution of landownership in China and England, I examined some important aspects of landownership, including the delineation of property rights, rent and tax, inheritance, and land accumulation. The comparative analysis indicates that social unit is an important determinant of landownership as well as culture. ${ }^{3}$ Family is the central

term might be to transplant Marx's theory of different stages in the historic development. See also Li and Jiang's (2005) non-traditional view on this issue.

${ }^{2}$ In his book, Institutions, Institutional Changes and Economic Performance, North admitted the impact of culture on institutions. Rather than regarding culture as a different factor, he seemed to include culture into a broad conception of institutions by using the word "informal constraints" to cover those "culturally derived".

${ }^{3}$ It is difficult to find a definition of culture as commonly received. Here I adopt what Thompson, Ellis and Wildavsky (1990) defined, "cultural bias refers to shared values and beliefs; social relations are defined as patterns 
feature of Chinese culture while individual is more important in the history of England. The same is true with landownership. In addition to the property right that family has over land, the ancient Chinese society was also organized in a way similar to family, making clear delineation of property rights impossible. This appears to be a central difference between the two countries. The different development paths of landownership were determined by their different cultures. England developed from feudalism to capitalism, from strict tenure system to free land market, while China sustained super-stability by strengthening the patriarchal clan system in both social philosophy and real life.

The next section briefly reviews the historic evolution of landownership in England and China, respectively, and then compares them in the third section. The fourth section explores why they have different trajectories. The fifth section discusses some further issues and concludes the paper.

\section{HISTORIC EVOLUTION OF LANDOWNERSHIP}

When reviewing the history of landownership in the two countries, we will focus on some basic features we are interested in, such as alienation, rent and tax, hereditary rules as well as land policy. ${ }^{4}$ Although it is difficult to ascertain from written documents what actually happened, our description in this paper will be based on a generally valid picture depicted by historians without the burden of restoring the precisely 'true' history. This section describes two different tracks of development. Feudal England was a combination of the Roman system and the Anglo-Saxon tradition. It has experienced an evolution from a very strict hierarchical

of interpersonal relations". I use the word 'culture' to represent the combination of social relations and cultural bias. In a broad sense, social unit could be regarded as part of culture. 
structure toward free land market. On the contrary, since very early China has established a land market that allowed free land alienation, but it had been trying to check the development of land market and private property rights by various means, the most important of which is the strengthening and expanding of patriarchal clan system. These two different stories of evolution provide the basis for our comparative analysis.

\section{England: from Feudalism to Capitalism}

Little is known about England before the Norman Conquest (AD 1066), which brought to the island a strong and universal system of feudalism that is essentially a hierarchical structure of tenure in landownership. It is obvious that the theory of tenure in the minds of Norman administrators were from the Continent. Hence, in order to know the origin of feudalism, it is necessary to trace back to Gaul, then a Roman colony, and further to Roman system.

In the early Roman society, the social and economic unit was a "patriarchal house community, familia, the state in little". ${ }^{5}$ It functioned simultaneously as the religious, political and juridical organization. It is very different from our modern notion of family (father, mother, and children). Propinquity and the power of the head cemented this social unit and determined its characteristics and internal organization. ${ }^{6}$ It was made up of a group united mainly by other relationships than those of consanguinity, and the larger and more successful it became, the more heterogeneous were its constituents (Noyes, 1936). ${ }^{7}$ All human beings and non-human objects

\footnotetext{
${ }^{4}$ I will examine landownership around the basic features of private property, as Cheung (1982) defined, "(a) the right to exclude others so that he alone may decide on its use; (b) the right to extract exclusive income from its use; and (c) the right to transfer or sell the property or resource to anyone as he sees fit."

${ }^{5}$ Outside familia there began to emerge super-familia government and law, which did not intrude with these units and itself "was largely a replica" of familia.

${ }^{6}$ Noyes, pp. 122-123. However, this social unit is not without controversy. Noyes wrote that many authorities thought that "the social unit was what we call a 'family' - that is, man, wife and progeny".

${ }^{7}$ Noyes, pp.106.
} 
as well as land belonged to the head. Later a distinction between free members of the household and slaves appeared to be made by using the word 'dominium'. There were also semidependents who attached to the house community for the sake of the protection given by the membership (manus). Succession to the pater was not decided by the custom of primogeniture but the testament of the father. The continuance of the patriarchal family was verified by "the evidence that many heredia remained in the same families for generations and even centuries, which would seem to be impossible if the familia were divided."8

With the development of Roman society, the super-familia government and law was greatly strengthened and began to influence within the familia. The classic Roman law included two kinds of power over persons according to their status as was within or without the family. The former was the Law of Persons; the latter the Law of Obligations. Meanwhile as regards power over material objects, there were again two kinds of laws according to whether they were within or without the family." 9 Thus, a clear distinction was made between within and without the familia. Later with the penetration of law, the biological related members became freer while the rest remained the same as before. Many others, as client (or amicus), gave themselves and their possessions to the patron so that their status could be assimilated to that of a member of the familia and received the patron's protection. Hence we see that the basic characteristic of Roman organization was the dual structure, i.e., the distinction between inside and outside familia. The law governed the outside sphere while the inside "was organized upon a hierarchical basis" with head, ranks and dependents. ${ }^{10}$

As one of the greatest empires of the ancient time, the organization of the Roman system greatly influenced Europe in the following centuries. In Gaul there was a lot of evidence of the

\footnotetext{
${ }^{8}$ Noyes, pp. 125 .
} 
Roman institution, transplanted almost intact. ${ }^{11}$ Although Roman Empire finally collapsed, the Roman economic organization upon the land persisted. Hence, after the Conquest the Norman dynasty imposed a system "which closely resembles these internal property relations of the Roman familia, though ... to apply on a nation-wide scale". ${ }^{12}$ That was the feudal system.

Feudalism was a form of dependent land holding -- the holding of land in return for the rendering of services, typically military service. "What was involved was both a personal relationship between superior and inferior, lord and vassal, marked by reciprocal duties of protection and service, and the granting of a benefice, that is, a parcel of landed estate to be enjoyed upon favorable terms, so long as the services due was faithfully performed." ${ }^{\prime 3}$ The highest lord was the King and at the bottom of this structure were those humble peasants. Between them were the numerous knights who provided his quota of service to the King by subinfeudation to other knights or peasants. The King's immediate grantee was called tenant in chief, and the service that the tenant owed to the knight was knight's fees. Theoretically, this sequence of subinfeudation could be rather long on a single parcel of land. There was no explicit limitation to the services upon a grant of land, and thus a diversity of tenures existed. Sir Thomas Littleton (1415-81) classified them as the following: Knight-service, Escuage or Scutage and Castle-gard, Grand Serjeanty, Frankalmoin, Frankmarriage, Socage Tenure, Petit Serjeanty, Burgage, and Fee Farm. Socage tenure was agricultural tenure of free peasants, in contrast to the tenure of villeinage. Knight-service and Escuage were military tenures. Fee Farm is for tenants who held land heritable for money rent. Frankmarriage was related with the entail in that it allowed no services due for three generations. Related with the different types of

\footnotetext{
${ }^{9}$ Noyes, pp.213.

${ }^{10}$ Noyes, pp. 21

${ }^{11}$ Noyes, pp.217.

${ }^{12}$ Noyes, pp.222.
} 
tenure were the incidents which the tenant must pay, such as Homage and Fealty, Aids, Relief and Primer Seisin, Wardship and Marriage, Escheat and Forfeiture. If a tenant failed to observe his duties, he would be tried in the feudal or seigniorial court of his lord. The royal court, held by the King, only cared about his tenants in chief without meddling inside the seigniorial courts. In this way we see a strict hierarchical system that was politically, economically, socially and legally defined.

With the development of the common law of land around the Real Actions (the 12th century to the 15 th century), the royal court gradually covered land disputes of free tenants. Glanvill was the first who began limiting the lord's court. He stated that "no man need answer in any court for his freehold land unless commanded to do so by the King's writ". ${ }^{14}$ Although real actions dealt with various complicated issues regarding title and developed around the concept of Seisin (like the concept of actual possession), they brought about a major transfer of jurisdiction over land and marked a fundamental change of legal ideas. It was argued that "what was involved was a movement from a world in which the central concept was one of reciprocal obligations, to one in which lord and tenant were conceived of as independently holding property rights, good against the world." 15 So it was the real actions, which took the free tenants under the protection of royal court, that initiated the destruction of the underpinnings of the feudal bond.

Under the original feudal system the tenant's fee was not heritable since "the tenure between lord and tenant was very much a personal affair which came to an end when the tenant

\footnotetext{
${ }^{13}$ Simpson, pp.2.

${ }^{14}$ Quoted from Simpson, pp.25.

${ }^{15}$ Simpson, pp.36-37. There were similar opinions, such as mentioned in Simpson's book that "the rise of the common law, operating through the early real actions, brought about a transfer of entitlements from lords to tenants."
} 
or lord died". ${ }^{16}$ The heirs of a tenant needed to buy back the lands. However in Glanvill's time the fee (or fief) had been firmly regarded as heritable. Meanwhile primogeniture was adopted as the rule of inheritance first in military tenures and later in socage. By Edward I's time primogeniture had become the common law of all tenures. A set of complex rules were developed to specify the sequence of inheritance depending upon the lineal and collateral relationships. A distinguished feature of the law in Glanvill's time was that will as well as death-bed gift was excluded.

In Glanvill's time the free alienation of land was not yet possible. The gradual change in practice led to the statute of Quia Emptores (AD 1290), which had that "from henceforth it shall be lawful for every freeman to sell at his own pleasure his lands and tenements". 17 Transfer of the land was carried out by substitution instead of subinfeudation. Then there arose the concept of the fee simple, which was both alienable and heritable. In 1285 the strong protest from the nobles made the statute De Donis Conolitionalibus drafted in purpose of preventing the alienation by holders of conditional fees. Nevertheless the statute of De Donis brought forth the doctrine of estates, which "involves a recognition not simply that the sum of possible interest the fee simple - may be cut up into slices like a cake and distributed amongst a number of people, but that all of them will obtain present existing interests in the land, though their right to actual enjoyment, to seisin in land, may be postponed". 18

After the invention of the doctrine of estates, the English system of landownership and land law evolved with the controversies on the right of alienation and the subsequent devices of promoting or preventing free alienation. In face of the limitation imposed by entails, collusive common recoveries was found to efficiently bar entails. Then an expediency called clauses of

\footnotetext{
${ }^{16}$ Simpson, pp.49.
} 
perpetuity was devised to restrain the alienation of entailed lands. In addition to the doctrine of estates and the doctrine of seisin, the widespread application of the use indicated how people avoided the feudal dues and facilitated conveyance. This was showed clearly in the victory of people who stood against the attempt to abolish the power of devise (drafting the will for land) in the 16th century. In 1536 the rebellion known as the Pilgrimage of Grace fully represented the anger toward the rigid doctrine of primogeniture. In 1540 "the Statute of Wills allowed landowners to devise two-thirds of their lands held in knight-service, and all their lands held in socage". ${ }^{19}$ In this way the King could still obtain the feudal dues. Nonetheless by intelligently applying a device made up of the combination of the use and the will the landowners could eventually evade the Crown's dues. Again, in order to overcome the seemingly insuperable entails, new rule was found. In the Duke of Norfolk's Case, landowner was not allowed to settle the devolution of land too far into a future which he could not foresee. In return, the settlers devised more complex form of settlement to keep the land in the family perpetually. In spite of all these controversies a trend toward a free land market could be clearly observed.

From the 15th century on the copyhold tenants' position began to improve. They were protected by both the common-law courts and the Chancellor. Free alienation of the copyhold land was gradually permitted.

In retrospect of the post-medieval land law, it is obvious that complex forms were abundant. On the other hand, all these complexities and peculiarities reflected the actual development of landownership in practice as well as how difficult it was for the old legal framework to adjust to the needs of social and economic development. Hence from the seventeenth century and in the nineteenth century at its peak, there arose the movement for

\footnotetext{
${ }^{17}$ Quoted from Simpson, pp.54.
} 
reform. The British legislation implemented some of the reform proposals in the middle of the 19th century and in 1920s. Although much of what those new laws did was to regularize or slightly simplify some practical rules which already existed, it was until then that the evolution of the system of landownership from feudalism to capitalism had been completed.

\section{China: More Limitations within a Stable Evolution}

China has probably the longest independent history in the world, as well as a wealth of written materials. As to information regarding land issues before Qin Dynasty (BC 221 - BC 207), however, there are many controversies and moot points due to shortage of written documents. Nevertheless we have to trace back beyond Qin Dynasty for two reasons: (1) Confucianism originated from that period of time; (2) the 'ideal' model of landownership in the minds of ancient Chinese scholars throughout the recent two thousand years, namely the Well Field System, only existed at that time.

In the Zhou Dynasty (BC 1100? - BC 256) the political system was similar to the feudal system. $^{20}$ The King distributed lands to relatives and vassals and thus set up a patriarchal hierarchy. This structure was constructed according to the rule that "those with the same surname were related by kinship while those with different surname were related by marriage". ${ }^{21}$ However the system of landownership was different from feudal system. "All land under the sky

\footnotetext{
${ }^{18}$ Simpson, pp.87.

${ }^{19}$ Simpson, pp.191.

${ }^{20}$ Under the traditional Marxist interpretation of Chinese history, the Zhou Dynasty was regarded as a slavery society. This was seen fit into Marx's social development stages. However there are different opinions on this. Li and Jiang (2006, pp.35) think that Xi Zhou was already a feudal system, similar to that in Western Europe. They regard the conventional "feudal" system in China's long history (from Qin Dynasty to Qing Dynasty) as one dominated by independent landlords (Feng Jian Di Zhu Zhi), which is very different from the feudal system in England.

${ }^{21}$ Zhou Zhuan, from Cheng, pp.6.
} 
belong to the King". 22 The distribution of land to the peasants followed the rule known as the Well Field System. "Each well had nine hundred $m u$, in the middle of which was public land. Eight families each cultivated one hundred $m u$ of the other fields while they cooperated in tilling the public land. Only after tilling the public land could they till on their own lands." ${ }^{23}$ In spite of the divergent interpretations about this system, some common features could be recognized: (1) the land belonged to the King, but it was distributed to each family to cultivate; (2) there existed public land, the product of which went to the King; (3) peasants had to pay rent; (4) alienation of land was forbidden.

After the collapse of the Zhou Dynasty, the following ChunQiu (BC 770 - BC 476) and the Warring States (BC 475 - BC 221) period experienced an accelerating process of strengthening private ownership. For example, Shang Yang, the prime minister of the Qin State, "abolished the Well Field System, cultivated new land, ..., permitted people to buy and sell land."24 Meanwhile, the society had undergone great changes. Gu, an ancient Chinese historian, commented in his book Ri Zhi Lu that "in the ChunQiu there were still memorial ceremonies and strict rituals while in the Warring States nothing of those remained; in the ChunQiu patriarchal clanship was still mentioned while in the Warring States no words about those; ...; all these happened during a period of 133 years." 25 All these developments should be at least attributed to the strong competition among the warring states and they eventually led to the first unified dynasty, the Qin Dynasty.

\footnotetext{
22 Jing, pp.11.

${ }^{23} \mathrm{Wu}, \mathrm{pp} .143$. li and $m u$ are traditional Chinese measures of length and area, about 500 meters and 667 hectares respectively. there are many different opinions about the Well Field System. Even its existence is questioned by some scholars.

${ }^{24}$ TongDian ShiHuo, quoted from Jing, pp.12.

${ }^{25}$ From Cheng, pp.30.
} 
When and after the Qin State unified China, it began to force large scale migration, especially former nobles, to cultivate frontier land. As a result, the old system was destroyed and some kind of private landownership was established, though land was still said to belong to the emperor. ${ }^{26}$ In BC 216, the Qin emperor ordered all people to declare the actual quantity of land they possessed so that rent could be calculated. ${ }^{27}$ This showed that free alienation and inheritance of land were legally supported. At this time peasants were required to submit rent and tax (fu and shui) to the central government as well as military service and labor service (fuyu and $y a о y u)$. Later, $f u$ and shui were combined together and the military services could be substituted with money.

Since the Qin Dynasty the basic system of landownership had remained almost unchanged. During this long period of time, in spite of some new changes brought into China by the invading nomadic nations, the basic features of landownership were stable. This stable state was accompanied with (to some degree sustained by) cyclical land reform and peasant uprisings. Though landowners changed after those cyclic events, the form of landownership in the new dynasty was almost the same as in the old dynasties. However, besides the general stabilization of the system there were some important trends in the two thousand years' development.

Although private landownership spread rapidly during the period of the Warring States (BC 475 - BC 221), slavery, tenure and private ownership had since then co-existed for two thousand years. In this process slavery gradually disappeared, while the tenure system had greatly developed. In the Song Dynasty many peasants became tenants and the tenure system had spread to a large scale. "Then the landlords who constituted $1 \%$ of the population occupied

\footnotetext{
${ }^{26}$ This is also a moot point. For some it was national landownership, and for some such as Kang Chao it was private landownership, while for the others it was the co-existence of multiple forms of landownership (Hu). I will discuss this later.

${ }^{27}$ Jing, pp. 12.
} 
$70 \%$ of cultivated land, while tenants and half-tenants (people who rented land and still owned a little) who constituted more than $80 \%$ of population owned less than $20 \%$ of cultivated land.",28 Even government-owned land could be leased out. The structure of tenure became more complicated and some people began to earn money by subleasing land to peasants. This was called bao dian. From the Song Dynasty and through the Ming Dynasty, perpetual tenure system (Yong dian) was developed. The tenant then had both the right of perpetually cultivating the land and the right to alienate or sublease this right. The tenant's right was called tian mian quan while the landlord's was called tian di quan. In this way several people could simultaneously have interests on a parcel of land. The large-scale development of the tenure system had important consequences in the history.

The spread of tenure implied the growth of land accumulation and the bankruptcy of small landowners who cultivated land themselves. Since these small landowners shouldered the heavy burden of national rent and tax, which was vital for a strong central government, and since land distribution was also a politically sensitive issue, government responded to this problem repeatedly throughout the history. The land policy of almost every dynasty focused on encouraging and fostering small landowners. In the Han Dynasty (BC 206 - AD 220), Emperor Wang Mang issued the order Wang Tian Ling which "forbade any alienation of land and forced any family who possessed land more than one well and had less than eight male family members must give part of their land to neighbors." 29 Three years later this order was revoked because of the social disturbance it caused. Another famous land reform policy, known as Jun Tian Ling, was carried out by the Tang Dynasty (AD 618 - AD 907). Under that law, government would give each adult male perpetual land of twenty mu, called yong ye tian, and kou fen land of $80 \mathrm{mu}$.

\footnotetext{
${ }^{28}$ Jing, pp. 24.
} 
Yong ye land could be inherited forever, while kou fen land was returned to the government after the man died or reached 60 years old. ${ }^{30}$ Behind these two typical land reform policies and the others adopted by each dynasty we can easily see the shadow of the Well Field System, which was regarded as the ideal model by scholars in almost every dynasty. Nevertheless, all these laws soon failed or gradually became loosened.

Another trend in the history that had significant impact on landownership was the development of patriarchal clan system. Although the original patriarchal clan system had been quite loosened since the Warring States, from the Song Dynasty (AD 960 - AD 1279) it had been strengthened and expanded. Usually land within a patriarchal clan could not be bought or sold. Even if it must be sold, the relatives within the clan had the priority to buy. ${ }^{31}$ In some regions there existed common land within the clan that was called si tian or she tian. They were created to help the poor within the clan. Some people also set up charity storage of grain ( $y i$ chang) for the clan in case of natural disaster or famine. When famine struck the countryside, rich families often donated food to relieve the poor clansmen. During the time of social crisis or turmoil, the patriarchal clans were often enlarged and strengthened and became more important. Economically, they became large production units and militarily, they formed armed bands to protect themselves. For example, in the Three States' time (AD 220 - AD 280), Chou Tian, a rich landlord and later a general, "led the relatives, clansmen and dependents about several hundreds in total, into Mount $\mathrm{XuWu}$ and chose some remote and strategic place to live and cultivate. .... Many people went there to seek refuge and soon in several years' time there

\footnotetext{
${ }^{29}$ Cheng, pp.62.

${ }^{30}$ Jing, pp.17.

31 Jing, pp. 20.
} 
gathered five thousand families. ${ }^{32}$ Throughout the two thousand years' time we saw the spread and strengthening of patriarchal clan system, both ideologically and practically.

As mentioned above, it had been established very early that land could be inherited. In Chinese history partition of the heritage as the hereditary custom prevailed. After the Tang Dynasty the law explicitly stipulated that "land, house and chattel must be divided among brothers". ${ }^{33}$ In the Qing Dynasty (AD 1644 - AD 1911), the law Da Qing Lu Li ordered that "as to the partition of land and property, it could be equally inherited only by sons no matter his mother was the wife, concubine or maid". ${ }^{34}$ Now in the countryside or even in the city, this rule is still applicable. Will and primogeniture were never dominant in Chinese history, except for the inheritance of the Crown.

The rent and tax also underwent a process of reform. Before the middle of the Tang Dynasty, rent and tax collected by the government were combined together and they were levied on persons instead of land. Later the Tang Dynasty reformed the law to separate capitation from rent and tax. In the Ming Dynasty (AD 1368 - AD 1644) all rent, tax and service were combined together according to the Whole Whip Act (Yi Tiao Bian). Finally in 1727, the Qing Dynasty made the poll tax fixed and levied the amount of rent and tax from the increased population on land. Throughout these reforms an obvious trend was that "the rent and tax levied on land and property became more important, while those levied on person and household became secondary." 35

Since the middle of the nineteenth century, the invasion of the industrialized countries had forced China to change its historical trajectory. Since then the Chinese people have

\footnotetext{
${ }^{32}$ Weishu Tianchou, quoted from Cheng, pp.117.

${ }^{33}$ Tang $\mathrm{Lu} \mathrm{Su} \mathrm{Yi,} \mathrm{quoted} \mathrm{from} \mathrm{Jing,} \mathrm{pp.20.}$

${ }^{34}$ Jing, pp. 20.

${ }^{35}$ Jing, pp. 19 .
} 
experienced various political, social and economic changes. On the one hand, it is still difficult to fit Chinese society into standard Western academic taxonomy such as feudalism or capitalism; on the other hand, it is easy to see that some basic features of landownership remained the same. Later we will analyze how these historic developments were affected by the culture and social structure of China.

\section{COMPARISON: SIMILARITIES AND DIFFERENCES}

It is very clear that China and England had two very different tracks for the evolution of landownership. However, due to their mutually independent development, the differences in time, geographic environment and even the stages of social development could not prevent us from extracting some general conclusions from a comparative study. Family seemed to be of great importance in the early stage of each society. Partition as hereditary customs could be found in both countries. Later tenure system became dominant and the simultaneously polarizing process of landholding was observed. In spite of these similarities, the great difference in the development path, the change of hereditary rules, the form of rent and tax, and delineation of property rights, marked the different cultural background of the two countries.

\section{Similarities}

Although the differences between the two countries are probably more obvious than their similarities, the common features they share are very important to our understanding the evolution of landownership. First, in the early stages of their histories family played an important role in the structure of landownership. In Roman society family, or more accurately kinship, was the nucleus of the "house community" or familia. It was "a fellowship of 
traditional consanguinity" ${ }^{36}$ The situation of England just before the Norman Conquest indicated the existence of complex and unsystematic patterns of landholding "upon the remains of the ancient rural community, itself a product of the old tribal arrangements with its farreaching family ties". ${ }^{37}$ This point is supported by the "open-field system" of tribal custom and the existence of the common land inside the later manors. The same was true for China in the time before the Warring States. The prominent feature of the Zhou Dynasty (BC 1100? - BC 256) was its emphasis on the rituals of ancestral worship and patriarchal clanship. It was certainly not a coincidence that Confucianism emerged at that time.

Second, with the development of the society, tenure (or more precisely, leases of limited tenures) appeared to spread and become a dominant form. In China, a trend from landholding by large numbers of small peasants to land accumulation into the hands of a small number of big landlords was very obvious both within a dynasty and throughout the two thousand years. The evidence is the widely documented increase of the number of tenants. In England, starting from the strict feudal tenure systems, "[t]he spread of leases of limited tenures, was a move towards greater flexibility." ${ }^{38}$ Given the population and land, the spread of lease or tenure indicated the accumulation of landholdings.

Third, within both countries, the distribution of land appeared to be regressive. That is, landholding seemed to move toward polarization. Although Chao denied this phenomenon in China, ${ }^{39}$ most Chinese scholars as well as historical records confirmed its long existence. For

\footnotetext{
${ }^{36}$ Noyes, pp. 40 .

${ }^{37}$ Noyes, pp.229.

${ }^{38}$ Harvey, pp.342.

${ }^{39}$ I do not agree with Chao for the following reasons: (1) Using the historic data he supplied, which was only from several villages, I could not find evidence of equalization or stability. (2) The geographic coverage of his data is not big enough. (3) All historians, both in nowadays and in the history, held the opposite opinions. (4) Even if no strong evidence of land accumulation had existed, it might just have been the result of other factors' counterbalance, such as family, culture and government policies. Chao did not specify the impact of these factors on his data.
} 
example, Su Xun in the Song Dynasty described the situation as that "lands were not owned by the cultivators while the owners did not till land themselves". ${ }^{40}$ In addition to the numerous accounts from historic materials, the frequent repetitions of government policies to try to check the polarizing process were also negative evidence. In England, although this phenomenon might not be so prominent as in China, it could still be observed. It was found that landholding in some place "underwent a sort of polarization process in the late fourteenth and fifteenth centuries". ${ }^{41}$ Harvey, in spite of some skepticism, admitted that "[w] hat we can be certain of is the accumulation of large holdings in so many places", and "after the mid-fourteenth century, the formation of some large holdings seems to have been a consistent feature of the local land market". ${ }^{42}$ Hence, given the sensitivity of this issue to society and economy, the regressive pattern of land distribution posed a problem to both countries.

Fourth, hereditary customs, which are very important to landownership, were the same in England in the pre-Conquest time as in China's long history. In Kent there was a custom by name 'gavelkind' that the land would descend to all male heirs of a tenant in equal degree. ${ }^{43}$ It was also observed that "in late Anglo-Saxon England there was widespread partible inheritance among the peasantry". ${ }^{4}$ Until now in Chinese countryside this is still the rule, which is called fen chia.

The last common feature of our interest is the prevalence and stability of land law. Although there were many changes to the English land law, Simpson concluded that "the law of property continues to play an extraordinary measure of historical continuity", and "[i]t is as if nothing fundamental has changed". The same is true to China. Having experienced many

\footnotetext{
${ }^{40}$ Jing, pp.24.

${ }^{41}$ Harvey, pp.340.

${ }^{42}$ Harvey, pp.342-343.

${ }^{43}$ Simpson, pp. 21.
} 
drastic changes and still changing, the landownership in contemporary China resembles many ancient features. Underlying the continuance of the law is our cultural heritage.

\section{Differences}

There are many differences between China and England, ranging from legal details to big theoretical issues. Here we are only interested in the basic features of landownership and its evolution over time. First and the most important difference is about alienation of land. From the feudalism to capitalism, England had undergone a process from no alienation to free alienation. But China is a very different story. In the Zhou Dynasty there was a rigid structure of landownership, quite similar to Roman society. After the turmoil and wars in the Warring States' time, free alienation of land spread all over the country. This happened in about BC 453 - BC 221. Though many people regard this point as the establishment of private property, and some even think this was the beginning of a market economy, ${ }^{45} \mathrm{I}$ do not think it was the same as private property or market economy in our modern sense. During the following two thousand years, especially after the Han Dynasty (BC 206 - AD 220), however, many political, economic and social measures were taken to check the development of a free land market. Since the Han Dynasty almost each dynasty had tried to implement some land reform in order to restore more or less part of the Well Field System. The typical administrative measures included forfeiting the rich families' land, setting the maximum quantity of landholding, mandatory migration, distributing land to poor peasants, and so on. Besides, the patriarchal clan system had been strengthened since the Song Dynasty (AD 960 - AD 1279) and its strict rules had great influence in limiting and checking free land alienation. In conclusion, two opposite trends existed in

\footnotetext{
${ }^{44}$ Harvey, pp.354.
} 
China (BC 206 - AD 1840) and England (AD 1066 - AD 1920), respectively. One was from free alienation of land toward cyclical attempts of more restrictions, while the other was from no alienation to a free land market.

In regard to the inheritance of land, the history appeared to be less complicated.

Throughout the history of China, the hereditary rule was fen chia that required equal partitioning among the male descendants. The notion that land is inheritable seemed never to meet any challenge. In feudal England, the tenant's land was not regarded as inheritable at the beginning. When a tenant died, the land reverted back to his lord. His heirs had to buy back their land from the lord. In 1100 the Coronation Charter of Henry I changed this to that the heirs no longer needed to buy back their land if they paid a just and lawful relief. ${ }^{46}$ Later on the rule of impartible inheritance (mostly primogeniture) dominated the history. The validity of a will on land began to be recognized only in the sixteenth century.

At very early time China had established a strong central government that required large amount of money, materials and services to support it. Rent and tax were levied on person rather than on land, although later this rule was gradually changed. The burden fell mostly on small landowners. In addition to the rent given to the landlord, the tenants had to pay rent and tax directly to the royal government. ${ }^{47}$ On the other hand, royal nobles and officials were exempt from rent, tax and services. Cheng listed them as: royal relatives (including people who had the same surname as the emperor), maternal relatives and nobles, officials, scholars. ${ }^{48}$ But in feudal England, peasants had no direct relationship with the King. The King collected revenue, services as well as knights directly from lords in chief, while the lords collected his fees from his

\footnotetext{
${ }^{45}$ For example, Kang Chao held this view.

46 Simpson, pp.49.

${ }^{47} \mathrm{Hu}, \mathrm{pp} .78$.

${ }^{48}$ Cheng, pp.55.
} 
tenants. Only in later post-medieval time the King began to levy direct tax on the people because of shortage of money to support the competition against rival countries. ${ }^{49}$ By comparison we see clearly the difference on rent, tax and servitude between the two countries. The English system was typically hierarchical while the Chinese system rather complicated.

One of the most important features of private property was the delineation of property rights. Although feudal England had no private property rights at all, its strict hierarchical structure had stipulated clear relationship between any two levels. The mutual relationship between lord and tenant was established through homage and fealty. One of the consequences of homage was that the lord had the duty to guarantee the title of the tenant and protect him, while fealty was the oath of the tenant's faith to services he owed to the lord. Later on accompanying the gradual establishment of property rights, exclusive delineation of landownership came into existence. That was why there emerged so complex a land law in England. In contrast, the Chinese might never have a clear delineation of landownership in the history. That is why there are so many different opinions about what type of landownership existed in China's recent twothousand-year history. One opinion (such as Marx) is that all land belonged to the emperor (or nationally owned), and so all people were the tenants of the emperor. Some think that several types of landownership co-existed. ${ }^{50}$ Chao (1986) argues that it was private landownership that fostered a long history of market economy in ancient China. ${ }^{51} \mathrm{Li}$ and Jiang (2005) hold a similar view; they think that the Chinese style feudal system was dominated by small landlords (Feng Jian Di Zhu Zhi). My thesis is that the problem arose from the absence of clear delineation of landownership (or property rights) in China. Hence the modern notions of property rights are difficult to apply. What we can be certain of is that the emperor, the nation, the patriarchal clan

\footnotetext{
${ }^{49}$ See North \& Thomas, The Rise of the Western World.
} 
and the landlord all had interests on the same parcel of land. That's why there were never the same or similar stories in Chinese history as those in British history that the King had to borrow money from his merchants. It must be very ridiculous to a Chinese emperor that a king had to borrow money from his subjects because in his mind all the land, money and human beings within the territory belonged to him. In a word, no matter what forms of landownership these two countries had, the existence of a clear delineation of property rights marked the difference between them.

After briefly reviewing and comparing the histories of landownership in these two countries, some general questions naturally arise. Why did these two countries have so different development paths of landownership? Or exactly, why were two opposite trends observed? Chao (1986) suggested that population pressure was the factor behind the choice of Chinese society. Continuous, accelerating population pressure in ancient China is a controversial point. ${ }^{52}$ Even if there were continuous population pressure, his conclusion would be weakened if we compare China with other countries. England, as well as most Western European countries, also experienced population pressure and subsequent Malthusian checks such as famines, wars and plagues. However they developed into another path. This simple comparison indicates that population pressure was not the key factor to understand the two countries' different choices. Then the question becomes: why did the two countries respond in different ways to the same problems? What caused their different institutional responses?

\footnotetext{
${ }^{50}$ Cheng, pp.102-109, and Hu, pp.11-15.

${ }^{51}$ Chao, pp.2-5.

${ }^{52}$ Many Chinese scholars claim that the total population of China was around 60 million from the Han Dynasty to the Ming Dynasty and only in the Qing Dynasty population began to increase quickly. See Jing, pp.28-29.
} 


\section{FAMILY VS. INDIVIDUAL}

To answer the above question, my central argument is that different social units in England and China affected the different social patterns of landownership, and different cultures (based on different social units) determined their different choices and different responses to the same problems about land.

Although a lot of units can be identified in a society, such as demographic unit, political unit, reproduction unit, residential unit, and so on, the basic unit is the one that other units are derived from or determined by. According to Macfarlane (1979), the basic social and economic unit in feudal England was individual, ${ }^{53}$ and later with the development of industry and commerce came the alienation of economic unit. That is, the production unit and business unit became factory, firm or 'enterprise'. However in China a different type of basic unit existed. The Chinese social unit and economic unit was family if we do not define family in the modern (or Western) sense that only include father, mother and children. The Chinese concept of 'family' is bigger, usually including at least three generations and close relatives. Relatives may not live together, but they often work together, do business together, and even respond as a whole toward outsiders and external events.

According to Macfarlane (1979), "a central and basic feature of English social structure has for long been the stress on the rights and privileges of the individual as against the wider group or the State. ... It is the view that society is constituted of autonomous, equal units, namely separate individuals, and that such individuals are more important, ultimately, than any larger constituent group. It is reflected in the concept of individual's direct communication with God." In the history of landownership in England, a lot of evidence supports this point. All

\footnotetext{
${ }^{53}$ I will not repeat most of his arguments, and here I will only discuss this issue in the context of landownership.
} 
feudal relationships, rules and laws dealt with individual persons. In contrast, the basic unit in China was family, or more precisely, 'expanded family'. ${ }^{54}$ All social, economic activities were organized around the family. For example, all rent, tax and services were levied on a family instead of on an individual person. All the ancient laws, such as the Well Field System, Wang Tian Ling, explicitly specified their subject as families. The hereditary rule can most clearly indicate the social unit. In England primogeniture "and complete individual property in real estate are intimately interlinked" 55 While in China partition of heritage implied that each son is given the birth right of inheritance, indicating the collectivist ownership of family property. So, if it is not too simplified, it could be concluded that the basic social unit or the unit of landownership in England was individual, while in China it was family. This was not very obvious when the children were little and the unit of reproduction seemed more important. However, after the children grew up, in England they had to support themselves with little possibility to depend on others (and even heritage) for subsistence, but in China they often remained inside the family even after they got married early due to the desire of parents to see the continuance of the family. The drive for family perpetuation often forced the Chinese young people get married much earlier than in England. ${ }^{56}$ In a word, the basic difference of landownership between the two countries was based on the difference between family and individual.

Macfarlane (1979) argues that English individualism was peculiar. This may be debatable. Harvey remarked cautiously about "a very stable balance in the conflicting claims of the individual and his family throughout the thirteenth, fourteenth, and fifteenth centuries." 57

\footnotetext{
${ }^{54}$ See Xiaotong Fei's book Countryside China for more detailed analysis on this issue.

${ }^{55}$ Macfarlane, pp.87.

${ }^{56}$ See Chao, pp. 8 for some detailed descriptions.

${ }^{57}$ Harvey, pp.354.
} 
Although this paper could not carefully analyze this issue due to its focus on comparative study, it is obvious that, relatively speaking, England was much more individualistic than China, which was peculiar in another way.

What is peculiar about China is not that its social unit and unit of ownership were family, which is also common in many other traditional peasantry societies, but that the concept of family in China is an expanded family. Expanding the concept further, the whole country including social life, social philosophy and culture was organized in a 'family' style. This cultural tradition was so strong that no religion ever superseded it. Confucianism best represents Chinese traditional culture. The central concept of Confucianism is family, although as mentioned above, it refers to quite an elastic range. In its narrowest sense it is our modern family, but in its broadest definition it could be the whole world. Confucianism emphasizes differential levels of a society that are organized around the individual, like ripples spreading out in concentric circles when a stone is thrown into the water. Emperor vs. vassal, father vs. son, close vs. remote relatives, husband vs. wife, the old vs. the young, leader vs. subject, ..., spreading out all these social relationships then the social structure of a Chinese society comes out. Thus Confucius claimed that cultivating one's moral character is the way to govern family, then from family to nation, and finally from nation to world. ${ }^{58}$ In this world view, everybody should be satisfied with his relative position in the society or even in the world. Here we see the source of the traditional philosophy of harmony between man and Nature. Meanwhile we can also see no explicit delineation between individual, family, nation and even world, but only in a relative sense. In any sense we can say that the importance of family in China is peculiar.

${ }^{58}$ Fei, pp.25-28. 
Given their different approaches to organize the society, England and China's difference in landownership could be easily explained. Because the difference between individual, family and nation is a relative concept in China, it is natural that no clear delineation of property rights was ever made. The rent and tax collected by the government was both for public finance and for the emperor's personal wealth. Besides individual, the patriarchal clan also has right to land in that they could stop the alienation of land and keep it inside the clan. Further more, all land belonged to the emperor, and he could collect rent, confiscate land, force people to migrate at his will. That might be the reason why rent and tax were never clearly separated in ancient China.

Now we can see the reasons behind the different trends in the evolution of landownership. Although China had established a more or less free land market as early as in the Warring States (BC 475 - BC 221), the Malthusian specter of population pressure and the negative effect of land accumulation led Chinese to check the free alienation of land, strengthen the patriarchal clan system and apply compulsory equalization of land distribution. From our modern perspective this might lower the economic efficiency and increase social equality. However, if we take into account of its particular culture, this was probably the best way available in the traditional Chinese society. First, nobody could ever think of individualization as a possible approach to those problems related to land ownership. Second, the Chinese culture morally and ideologically denounces wealth accumulation and social inequality, which were obviously opposite to the 'family' value. This was also reflected in the contempt toward merchants. That might be one reason why in China merchants had never achieved the same political status as their counterparts in post-medieval Europe. Throughout Chinese history there was always flow of capital from city to countryside, from commerce to agriculture. After merchants made money, they bought land in the countryside and became landlords. Comparing China with England, we can see an 
interesting role of land market. If there was not a relatively mature land market, then the merchants' could not spend their money purchasing land. That in turn might help the accumulation of industrial capital and eventually the industrial development. ${ }^{59}$ Third, given the technological level in ancient China, land accumulation could not result in significant scale economy. The big landlords also leased the land to many tenant families. The production unit was the same-family. Fourth, given the family-oriented culture, land accumulation could not lead to labor division. As Chao (1986) remarked, "the most powerful mechanism of redistribution in Chinese history was ... the family system. ..., the family system could make necessary adjustments over time to accommodate surplus population by a process of domesticating production unit." ${ }^{, 00}$ Another function of the family system is related to its hereditary rule. Under the partition rule, it is difficult to accumulate wealth for many generations. Hence, in the context of Chinese culture, this evolution path of landownership was probably the best way for both social and economic purposes. Free alienation of land was not eliminated while social development was sustained. This is probably the reason why Chinese "feudal" society remained so stable over more than two thousand years.

In England we see a different picture. The feudal system was imposed on Anglo-Saxon society by Norman knights. Although the Conquest probably fostered the peculiar individualism of England, as argued by Macfarlane (1979), its rigid structure checked the economic and social development. In face of Malthusian specter, the individualist culture brought about labor division as well as the prosperity of commerce and industry and capital began to play a more important role in economic development. Besides, the individualist culture, especially the

\footnotetext{
${ }^{59} \mathrm{Li}$ and Jiang (2006, pp.24-28, pp.454-458) argue that China's feudal landlord economy (Feng Jian Di Zhu Zhi Jing $\mathrm{Ji}$ ), on the one hand, helped the development of commerce and industry, but on the other hand, also became its bottleneck. They even think that it was not the self-subsistent natural economy, as the conventional wisdom put it, but rather a combination with market (commodity) economy.
} 
primogeniture custom of inheritance helped to accumulate wealth which was crucial to the development of capitalism. All these helped England to overcome the Malthusian specter and develop into modern capitalism with private property rights as the foundation.

\section{DISCUSSION AND CONCLUSION}

From our comparative study between England and China, it is easy to see that landownership as well as land law tends to be quite stable. Their fundamental features appear to be prevalent for a long time. The reason is related to social unit and culture. Since landownership basically reflects the relationship among people and their interests on land, its basic pattern was determined by the form of social unit that represents how people interact with each other. In feudal England, the social unit was the individual in a hierarchical structure and thus the landownership was of a hierarchical individual type. In China, since the social unit was family and the social philosophy was family-oriented, landownership seems to be a mixture of individual, family, patriarchal clan and nation (or emperor). This is similar to the situation within a traditional family, where there is no clear delineation of each other's rights on property and no one cares about the delineation. On the one hand, the form of social unit determines or influences social culture. On the other hand, culture carries the inertia of society and helps to maintain the continuance of the basic features of landownership.

Although some basic features of landownership tend to be stable, its evolutionary trend reflects the response to social and economic changes over time. Through the comparison between China and England it is found that land distribution appears to be regressive. A possible conjecture is that in a closed agricultural economy and under certain technological level,

\footnotetext{
${ }^{60}$ Chao, pp.9.
} 
land distribution tends to be a regressive process with free land alienation. ${ }^{61}$ Two different types of reaction appeared in England and China. Based on the individualist culture, England responded with higher social mobility, more labor division, and more industrial investment. The individualist culture injected strong incentive to the development of capitalism and helps to form capital by encouraging wealth accumulation. Finally England escaped the Malthusian specter. In China's case, however, the family-based culture mitigated the negative effects of landownership problems through its own mechanism. Nevertheless, there were many peasant rebellions and social turmoil in Chinese history. Chinese history shows a pattern of cyclic development that was based on relatively super-stable institutions and periodic attempts on limit private landownership. All these indicate its path dependence (North 1991) and help to explain why China did not develop into capitalism and why England became the birth place of industrialization.

A further question arises. Given that family is often the basic social unit in the traditional society, why did England and China choose different development paths? Greiff (1994) argues that individualist society is more inclined to develop legal, political, and second-party institutions while the collectivist society relies more on blood and place-based relations. His conjecture appears to be closely related to what we observe in the different historical trajectories of landownership in China and England. However, it could not explain why one society chose a more individualistic approach while another pick a collectivist path. Here I give some bold conjectures. For England, Norman Conquest and the following feudal system imposed on Anglo-Saxen society are obviously an important reason why it developed into an individualistic

\footnotetext{
${ }^{61}$ The reasons for the regressiveness include: (1) the principle of decreasing marginal revenue and population pressure determine that landlord will gain more advantages than peasants with the development of agriculture. David Ricardo's theory on rent also suggests that rent instead of wage captures the fruit of economic development.
} 
culture. But a more fundamental reason might be that England, as an island country, relied more on commerce especially at its later development stages. To China's large-scale agricultural economy, the biggest and most frequent risks are natural disaster and war. Given the technological level in ancient China, it was difficult and also less efficient to manage these largescale risks purely by legal and political institutions. During natural disasters and wars, the most reliable relief comes from relatives and neighbors. It was then not accidental that China adopted the social philosophy based on the expanded family in order to maintain a stable society.

North (1991) thinks that "[r]ulers devised property rights in their own interests and transaction costs resulted in typically inefficient property rights prevailing. As a result it was possible to account for the widespread existence of property rights throughout history and in the present that did not produce economic growth."62 The comparative study in this paper suggests that no rulers can really 'devise' property rights or landownership. It is social unit and culture that determine the form of landownership.

(2) The inelastic supply of land gives the landlord more bargaining power. (3) In face of natural disaster, small land owners are more vulnerable than big landlords.

${ }^{62}$ North, pp.7. 


\section{REFERENCES}

Chao, Kang. Man and Land in Chinese History: An Economic Analysis. Stanford: Stanford University Press, 1986.

Cheng, Shoushi. Zhong Guo Gu Dai Tu Di Guan Xi Shi Gao (The History of Landownership in China). Shanghai: People's Press, 1984.

Cheung, Steven N. S. Will China Go 'Capitalist'?: an Economic Analysis of Property Rights and Institutional Change. London: The Institute of Economic Affairs, 1982.

de Soto, Hernando. The Mystery of Capital: Why Capitalism Triumphs in the West and Fails Everywhere Else. New York, NY: Basic Books, 2000

Fei, XiaoTong. Xiang Tu Zhong Guo (Countryside China). Hong Kong: Joint Publishing Co.(HK), 1986.

Greif, Avner. "Cultural Beliefs and the Organization of Society: A Historical and Theoretical Reflection on Collectivist and Individualist Societies", Journal of Political Economy, 1994, vol.102, no.5.

Harvey, P. D. A. The Peasant Land Market in Medieval England. Oxford: Clarendon Press, 1984.

Hu, RuLei. Zhong Guo Feng Jian She Hui Xing Tai Yan Jiu (Research on Chinese feudal society). Beijing: Shan Lian Book Company, 1979.

Jing, Dechun. Zhong Guo Guo Ming Dang Tu Di Zhen Che Yan Jiu (Research on Land Policies of KMT). Beijing: Hai Yang Press, 1991.

Li, Wenzhi and Taixin Jiang. Zhong Guo Di Zhu Zhi Jing Ji Lun (On China's Feudal Landlord Economy: the Development of Feudal Landownership). Beijing: China Social Science Press, 2005. 
Macfarlane, Alan. The Origins of English Individualism: The Family, Property and Social Transition. New York: Cambridge University Press, 1979.

North, Douglass C. and Thomas, Robert Paul. The Rise of the Western World: A New Economic History. New York: Cambridge University Press, 1976.

North, Douglass C. Institutions, Institutional Change and Economic Performance. New York: Cambridge University Press, 1991.

Noyes, Charles Reinold. The Institution of Property: a study of the development, substance and arrangement of the system of property in modern Anglo-American Law. New York, Toronto, Longmans, Green and Co.; London, H. Milford, 1936.

Simpson, A. W. B. A History of the Land Law. Oxford: Clarendon Press, 1986.

Thompson, Ellis and Wildavsky. Cultural Theory. Boulder: Westview Press, 1990.

Wu, Hui. Jin Tian Zhi Kao Shuo (A Study on the Well Field System). Beijing: Agricultural Press, 1985. 